\title{
Postoperative fungal endophthalmitis caused by Trichosporon asahii treated with voriconazole
}

\author{
Endoftalmite fúngica pós-operatória causada por Trichosporon asahii tratada com voriconazol
}

Saban Gonul ${ }^{1}$, Sansal Gedik ${ }^{1}$, Banu Turgut Ozturk ${ }^{1}$, Berker Bakbak ${ }^{1}$, Bengu Ekincl Koktekir ${ }^{1}$, Suleyman Okudan ${ }^{1}$, Hatice Turk Dagl $^{2}$

\begin{abstract}
Postoperative fungal endophthalmitis is a rare but devastating complication of cataract surgery. Vitrectomy and intravitreal amphotericin B injection as well as administration of systemic antifungal agents have been suggested as optimal treatments for fungal endophthalmitis. However, this therapy may fail to eliminate fungal species resistant to current antifungal agents. The saprophytic fungus Trichosporon asahii is frequently observed as a cause of endogenous endophthalmitis in immunosuppressed patients. We report a case of postoperative endophthalmitis caused by T. asahii, resistant to amphotericin B. To the best of our knowledge, this is the first report of T. asahii endophthalmitis successfully treated with intravitreal and systemic voriconazole, pars plana vitrectomy, and removal of the intraocular lens and entire lens capsule.
\end{abstract}

Keywords: Endophthalmitis/etiology; Endophthalmitis/drug therapy; Postoperative complications; Phacoemulsification/complication;Trichosporon; Pyrimidines; Humans; Case reports

\begin{abstract}
RESUMO
Endoftalmite fúngica pós-operatória é uma complicação rara mas devastadora da cirurgia de catarata. A vitrectomia e injeção intravítrea de anfotericina $B$, bem como agentes fungicidas sistêmicos, têm sido sugeridos como tratamentos ideais para endoftalmite fúngica. No entanto, esta terapia pode falhar em erradicar as espécies de fungos resistentes aos agentes antifúngicos atuais. Uma dessas espécies de fungos é o fungo saprófita, Trichosporon asahii, que éfrequentemente observada, como causa de endoftalmite endógena, em pacientes imunodeprimidos. Relatamos um caso de endoftalmite pós-operatória causada por $\mathrm{T}$. asahii que é resistente a anfotericina $B$. Ao nosso conhecimento, este é o primeiro relato de endoftalmite por $\mathrm{T}$. asahii tratado com sucesso com voriconazol intravítreo e sistêmico, vitrectomia via pars plana, e remoção da lente intraocular e saco capsular.
\end{abstract}

Descritores: Endoftalmite/etiologia; Endoftalmite/quimioterapia; Complicações pós-operatórias; Facoemulsificação/complicações; Trichosporon; Pirimidinas/uso terapêutico; Humanos; Relatos de casos

\section{INTRODUCTION}

Trichosporon are saprophytic fungal species, which very rarely cause exogenous endophthalmitis and are possibly resistant to traditional antifungal therapy. Several endophthalmitis cases caused by Trichosporon species have been reported as a complication of fungemia in immunosuppressed patients and in one postoperative case ${ }^{(1,2)}$. We present a case of postoperative endophthalmitis caused by amphotericin B-resistant Trichosporon asahii. To the best of our knowledge, this is the first report of T. asahii endophthalmitis successfully treated with intravitreal and systemic voriconazole.

\section{CASE REPORT}

A 72-year-old man with a history of diabetes mellitus was admitted to our outpatient clinic with blurred vision, ocular pain, and redness in his left eye. He had undergone a cataract surgery on his left eye 1 month earlier at a different clinic. His symptoms had started 3 weeks after this surgery. His best-corrected visual acuities were 20/20 in the right eye along with perception of hand movements close to the face in the affected left eye. Slit-lamp biomicroscopy revealed a white flocculent mass with a moderate fibrin response and cellular reaction in the anterior chamber (Figure 1). Intraocular pressures measured by applanation tonometry were $16 \mathrm{mmHg}$ in the right eye and $14 \mathrm{mmHg}$ in the left eye. The fundus could not be visualized, and
B-scan ultrasonography revealed vitreous opacities with an attached retina. Hence, the patient was diagnosed with postoperative endophthalmitis and was treated with intravitreal injections of vancomycin $(1.0 \mathrm{mg} / 0.1 \mathrm{~mL})$, ceftazidime $(2.25 \mathrm{mg} / 0.1 \mathrm{~mL})$, and amphotericin $\mathrm{B}(5 \mu \mathrm{g} / 0.1 \mathrm{~mL})$, following a prompt vitreous tap and puncture of the anterior chamber to establish a culture. The patient then received topical fortified vancomycin $(50 \mathrm{mg} / \mathrm{mL})$, ceftazidime $(100 \mathrm{mg} / \mathrm{mL})$, amphotericin $B(0.5 \mathrm{mg} / \mathrm{mL})$, and dexamethasone every hour as well as oral moxifloxacin (400 mg) once daily. However, the patient's vision deteriorated to the point where he was only able to perceive light, and the intraocular inflammation also worsened. Three samples from the initial vitreous tap were positive for Trichosporon species. All Trichosporon isolates were identified by standard laboratory procedures (morphological identification) and the VITEK 2 (bioMerieux, France) automated system. All three isolates were identified as T. asahii (Figure 2). Therefore, systemic amphotericin B (400 mg once daily) was added to the existing treatment, and a 23-gauge pars plana vitrectomy with silicon oil infusion and intravitreal injections of amphotericin B, vancomycin, and ceftazidime was performed 18 days post admission. Cultures that obtained during vitrectomy surgery again revealed $T$. asahii. Thus, the patient was administered another injection of intravitreal amphotericin B; however, the inflammation did not improve. For antifungal sensitivity tests, the minimum inhibitory concentrations (MIC) were determined using the reference broth
Submitted for publication: May 16, 2014

Accepted for publication: November 24, 2014

${ }^{1}$ Department of Ophthalmology, Faculty of Medicine, Selcuk University, Konya, Turkey.

2 Department of Microbiology, Faculty of Medicine, Selcuk University, Konya, Turkey.
Funding: No specific financial support was available for this study.

Disclosure of potential conflicts of interest: None of the authors have any potential conflict of interest to disclose.

Corresponding author: Saban Gonul. Department of Ophthalmology. Faculty of Medicine, Selcuk University - Konya - Turkey - E-mail: drsabangonul@gmail.com 
microdilution method, according to Clinical and Laboratory Standards Institute document M27-A3. The MIC of fluconazole, voriconazole, amphotericin $B$, and caspofungin against the $T$. asahii isolate were $2 \mu \mathrm{g} / \mathrm{mL}, 0.12 \mu \mathrm{g} / \mathrm{mL}, 2 \mu \mathrm{g} / \mathrm{mL}$, and $4 \mu \mathrm{g} / \mathrm{mL}$, respectively, demonstrating that the organism was resistant to amphotericin B but sensitive to voriconazole. Therefore, topical and systemic antifungal therapies were switched from amphotericin B to voriconazole $(1 \mathrm{mg} / \mathrm{mL}$ topically), and intravitreal voriconazole $(25 \mu \mathrm{g} / 0.1 \mathrm{~mL})$ was also administered. Intravitreal voriconazole was repeated 3 days later. This therapy produced a significant clinical improvement with decreased intraocular inflammation, and it was discontinued after 8 weeks. Three months after the patient had been admitted, his vision was 20/100 with complete resolution of the endophthalmitis.

However, 6 months after the original cataract extraction, the infection recurred with a visual acuity of hand movements close to the face, and the patient underwent another pars plana vitrectomy with silicon oil infusion, removal of the intraocular lens and entire lens capsule, and intravitreal injection of voriconazole. Intravitreal voriconazole was also repeated 3 days after the second pars plana vitrectomy. Cultures of the vitreous and intraocular lens were positive for T. asahii. Therefore, systemic voriconazole was administered orally at a dosage of $200 \mathrm{mg}$ twice daily for the next 2 months. Although inflammatory activity completely disappeared after this therapy, the patient's visual acuity remained at 20/100 (Figure 3). No recurrence was observed at the 1-year follow-up.

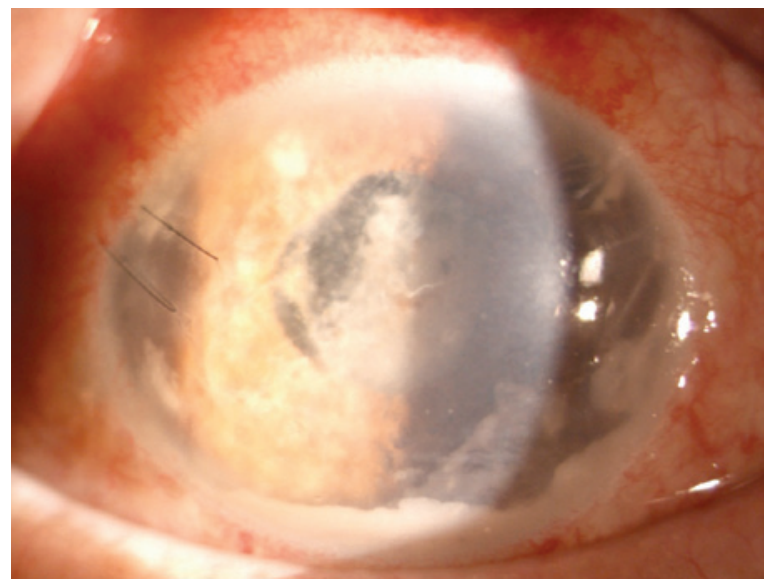

Figure 1. Slit-lamp photograph showing a white flocculent mass with a moderate fibrin response and cellular reaction in the anterior chamber.

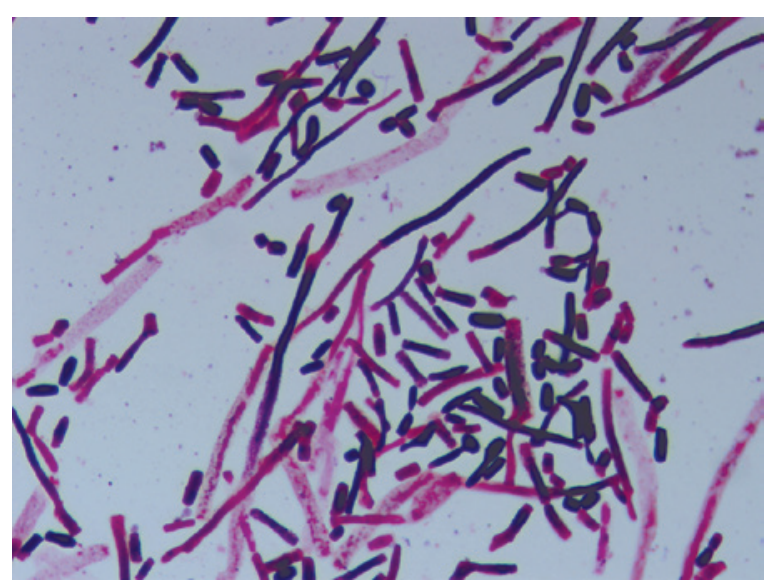

Figure 2. Photomicrograph of a Gram-stained colony isolated on Sabouraud dextrose agar, demonstrating budding yeasts, hyphae, and arthroconidia.

\section{DISCUSSION}

Trichosporon species, formerly known as Trichosporon beigelii, rarely cause exogenous endophthalmitis and comprise a number of genetically distinct species that are pathogenic to humans ${ }^{(1,3,4)}$. T. asahii is also among the Trichosporon species that are frequently observed in cases of immunocompromised patients ${ }^{(2-4)}$. In addition, these species may exhibit some differences in their antifungal susceptibility profiles ${ }^{(3,4)}$. Marc et al. reported a case of postsurgical endophthalmitis that was caused by $T$. beigelii in an immunocompetent patient with systemic and ocular sarcoidosis ${ }^{(1)}$. In their case report, the patient was successfully treated with oral fluconazole. In addition, they postulated that sarcoidosis may have predisposed their patient to fungal endophthalmitis because patients with this disease may have a form of immune dysfunction. Similarly, our patient had no other immunocompromising risk factors, except for diabetes mellitus, which is associated with impaired leukocyte function ${ }^{(5)}$. Therefore, diabetes mellitus may have predisposed our patient to T. asahii endophthalmitis.

In vitro studies have shown that voriconazole is very effective against several fungal species that are resistant to the traditional antifungal therapy ${ }^{(3)}$. In addition, some case reports demonstrate the successful use of systemic voriconazole in treating fungal endophthalmitis ${ }^{(2,6)}$. In addition, intravitreal voriconazole concentrations of up to $25 \mu \mathrm{g} / \mathrm{mL}$ cause no electroretinographic changes or histologic abnormalities in the rat retina ${ }^{(7)}$. However, the use of voriconazole in treatment of Trichosporon endophthalmitis has been limited. To the best of our knowledge, it has never been used to treat postsurgical fungal endophthalmitis caused by T. asahii. Moreover, voriconazole is reportedly the most effective agent against Trichosporon species in vitro ${ }^{(3,4)}$. In addition, in our patient, the pathogen was resistant to amphotericin B. Therefore, we used intravitreal and systemic voriconazole. Furthermore, systemic or topical voriconazole should be ideally administered as follow-up to intravitreal voriconazole because voriconazole is rapidly metabolized after a single intravitreal injection $^{(8)}$. Hence, we used topical and systemic voriconazole after both the first and second pars plana vitrectomies.

Trichosporon species have the ability to adhere and form biofilms on implanted devices ${ }^{(4)}$ such as intraocular lenses (IOL). This ability has been associated with infections by invasive Trichosporon species because these pathogens evade host immune responses and antifungal agents ${ }^{(4)}$. In our case, the patient also had an IOL. Therefore, the ability of T. asahii to form biofilms on IOL may account for the occurrence and progress of the endophthalmitis in our patient.

In our case, recurrence after complete resolution of the endophthalmitis was observed. However, because we had not obtained the patient's consent, we were unable to remove the $\mathrm{IOL}$ and entire lens

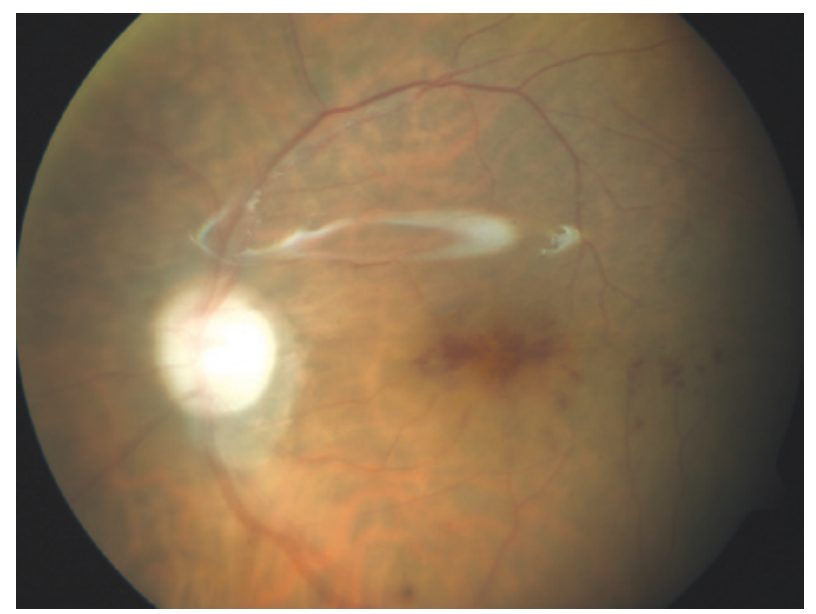

Figure 3. Appearance of the fundus 3 months after treatment discontinuation. 
capsule, both of which could be a reservoir of organisms, in the first pars plana vitrectomy; the recurrence was probably attributable to this. Although intravitreal and systemic voriconazole was used after the first vitrectomy, recurrence was observed 2 months after complete resolution of the endophthalmitis. In addition, after we used intravitreal and systemic voriconazole along with the removal of the $\mathrm{IOL}$ and entire lens capsule during the second pars plana vitrectomy, no recurrence was observed. Therefore, a possible reason for the recurrence in our patient was the biofilm of T. asahii that may have formed on the IOL.

In conclusion, voriconazole with intraocular debridement enabled successful resolution of the infection when treating endophthalmitis caused by amphotericin B-resistant T. asahii, demonstrating the importance of the removal of the IOL and entire lens capsule and also of injecting voriconazole intravitreally.

\section{REFERENCES}

1. Spirn JM, Roth DB, Yarian DL, Green SN. Postoperative fungal endophthalmitis caused by Trichosporon beigellii resistant to Amphotericin B. Retina. 2003;23(3):404-5.
2. Walia H, Tucci VT, Greene JN, Tordilla-Wadia J, Kelty P, Walia S. A case of endogenous trichosporon endophthalmitis treated with micafungin and voriconazole. J Glob Infect Dis. 2009;1(1):71-4

3. Rodriguez-Tudela JL, Diaz-Guerra TM, Mellado E, Cano V, Tapia C, Perkins A, et al. Susceptibility patterns and molecular identification of Trichosporon species. Antimicrob Agents Chemother. 2005:49(10):4026-34.

4. Colombo AL, Padovan AC, Chaves GM. Current knowledge of Trichosporon spp and Trichosporonosis. Clin Microbiol Rev. 2011;24(4):682-700.

5. Berrou J, Fougeray S, Venot M, Chardiny V, Gautier JF, Dulphy N, et al. Natural killer cell function, an important target for infection and tumor protection, is impaired in type 2 diabetes. PLoS One. 2013;8(4):e62418

6. Breit SM, Hariprasad SM, Mieler WF, Shah GK, Mills MD, Grand MG. Management of endogenous fungal endophthalmitis with voriconazole and caspofungin. Am J Ophthalmol. 2005;139(1):135-40.

7. Gao H, Pennesi ME, Shah K, Qiao X, Hariprasad SM, Mieler WF, et al. Intravitreal voriconazole: an electroretinographic and histopathologic study. Arch Ophthalmol. 2004; 122(11):1687-92. Erratum in: Arch Ophthalmol. 2005;123(1):130.

8. Hariprasad SM, Mieler WF, Lin TK, Sponsel WE, Graybill JR. Voriconazole in the treat ment of fungal eye infections: a review of current literature. $\mathrm{Br} J$ Ophthalmol. 2008; 92(7):871-8.

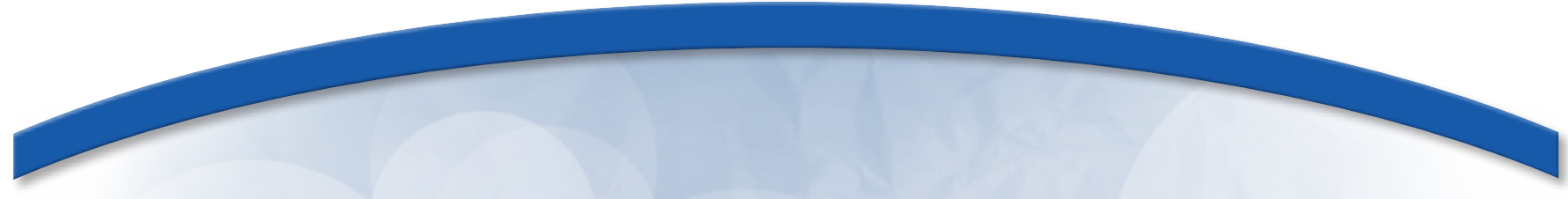

\title{
Simpósio Internacional do Banco de Olhos de Sorocaba - SINBOS 2015
}

\section{2 a 24 de outubro de 2015}

\author{
Hospital de Olhos de Sorocaba
}

Sorocaba - SP

\section{Informações:}

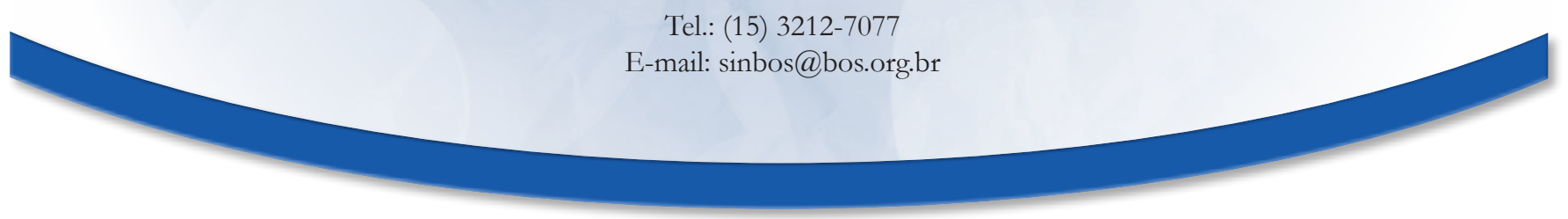

